\section{Nytt kolesterol- senkende middel etter hjerteinfarkt?}

Tilleggsbehandling med ezetimib etter akutt hjerteinfarkt reduserer nivået av LDL-kolesterol, men reduserer ikke risikoen for å dø.

Ezetimib er et kolesterolsenkende middel som hemmer opptak av kolesterol fra tarmen. I en randomisert, dobbeltblind studie med om lag 18000 pasienter med akutt hjerteinfarkt ble det undersøkt om behandling med ezetimib i tillegg til simvastatin reduserer risikoen for død, nye infarkter eller iskemisk hjerneslag (1).

Tilleggsbehandling med ezetimib ga lavere nivå av LDL-kolesterol i serum sammenliknet med behandling med simvastatin alene. Gruppen som fikk ezetimib, hadde en beskjeden reduksjon i risiko for nytt hjerteinfarkt og iskemisk hjerneslag, mens risikoen for død var den samme. Andel pasienter som avbrøt behandling på grunn av bivirkninger var lik i de to gruppene.

- Denne studien gir støtte til LDL-hypotesen, nemlig at å senke LDL-kolesterolnivået til meget lave nivåer reduserer risikoen for alvorlige kardiovaskulære hendelser hos personer med akutt infarkt, uavhengig av medikament, sier førsteamanuensis Sameline Grimsgaard ved Institutt for samfunnsmedisin, Universitetet i Troms $\varnothing$ - Norges arktiske universitet.

- Mange studiedeltakere var overvektige, forekomsten av kardiovaskulære risikofaktorer var høy og $84 \%$ var menn med snittalder over 60 år. Resultatene vil derfor ha gyldighet for denne gruppen. Studiedesignet var godt og resultatene konsistente. Vi må forvente at studien vil utløse en diskusjon om hvordan vi bør behandle pasienter med akutt hjerteinfarkt, sier Grimsgaard.

\section{Martine Rostadmo}

Tidsskriftet

\section{Litteratur}

1. Cannon CP, Blazing MA, Giugliano RP et al; IMPROVE-IT Investigators. Ezetimibe Added to Statin Therapy after Acute oronary Syndromes. N Engl J Med 2015; 372: 2387-97.

\title{
Mors alder ved fødsel og barns utvikling
}

\section{Studier har vist at både lav og høy maternell alder er assosiert med økt risiko for uheldige konsekvenser for barnet. I en ny kohortstudie er denne sammenhengen unders $\varnothing$ kt for lavinntektsland}

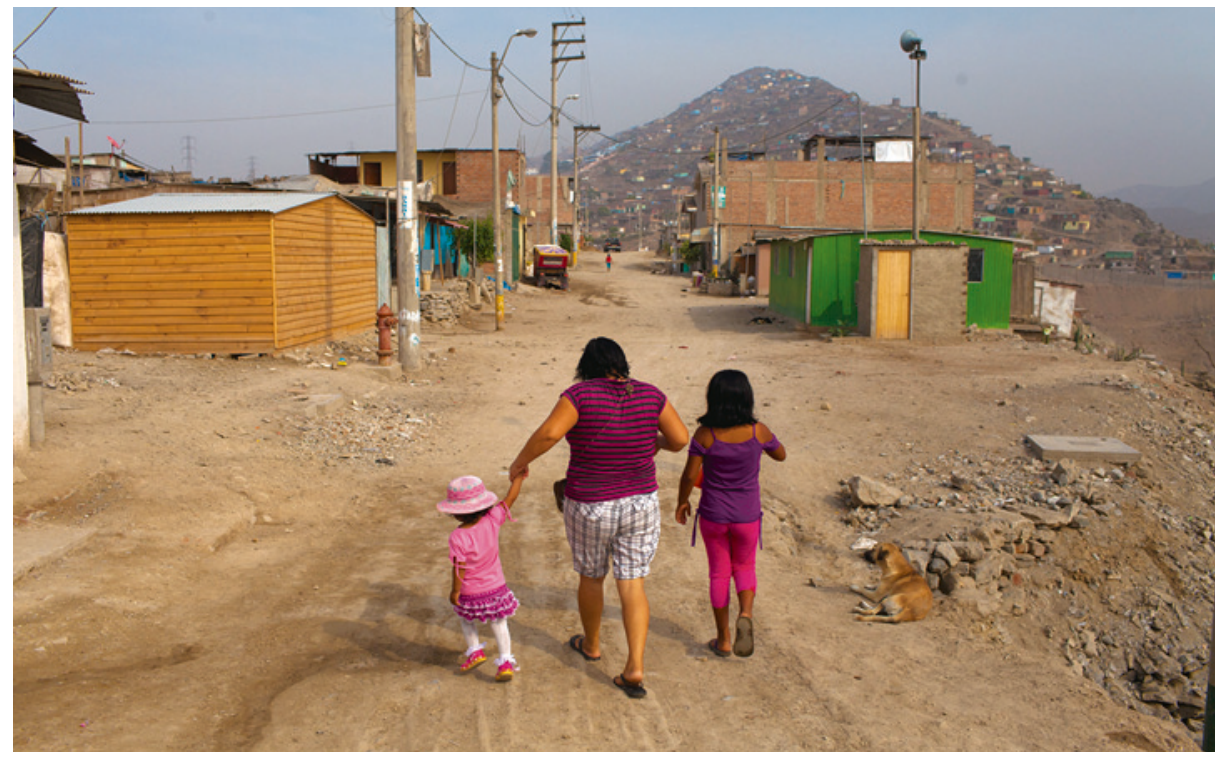

Illustrasjonsfoto: Corbis/Scanpix

Tidligere studier, de fleste fra høyinntektsland, har funnet at ung maternell alder er assosiert med økt risiko for for tidlig fødsel, intrauterin vekstretardasjon, spedbarnsdødelighet, underernæring og at barnet får lavere utdanning, mens høy maternell alder er assosiert med $ø$ kt antall dødfødsler, for tidlig fødsel, intrauterin vekstretardasjon og kromosomavvik.

I en prospektiv studie, som nylig ble publisert i The Lancet Global Health, har man undersøkt betydningen av mors alder i lavog mellominntektsland (1). Materialet omfatter om lag 20000 mødre fra Brasil, Guatemala, India, Filippinene og Sør-Afrika, rekruttert i perioden 1969-89. Ung maternell alder ( $\leq 19$ år) var assosiert med økt risiko for lav fødselsvekt, for tidlig fødsel, vekstavvik ved toårskontrollen lunder normalen på vekstkurven) og avbrutt videre skolegang for barnet sammenliknet med 20-24 år gamle mødre. Høy maternell alder ( $\geq 35$ år) var assosiert med økt risiko for for tidlig fødsel, men mindre vekstavvik ved toårskontrollen og mindre frafall fra videre skolegang sammenliknet med 20-24 år gamle mødre.

Forskerne konkluderer med at barn av unge mødre i lav- og mellominntektsland er uheldigere stilt ved fødsel og i forhold til ernæring og skolegang. De anbefaler at innsatsen økes for å forebygge graviditet i ung alder og at unge mødre bør få hjelp til å forbedre barnas ernæring og utdanning.

\section{Liv-Ellen Vangsnes}

Tidsskriftet

\section{Litteratur}

1. Fall CHD, Sachdev HS, Osmond C et al. Association between maternal age at childbirth and child and adult outcomes in the offspring: a prospective study in five low-income and middle-income countries (COHORTS collaboration). Lancet Glob Health 2015; 3: e366-77. doi: 10.1016/S2214-

$109 \times(15) 00038-8$ 